\title{
Validation of HPLC, DPPH` and nitrosation methods for mesalamine determination in pharmaceutical dosage forms
}

\author{
Janice Aparecida Rafael*, José Roberto Jabor, Rúbia Casagrande, Sandra Regina Georgetti, \\ Maria de Fátima Borin, Maria José Vieira Fonseca
}

Departamento de Ciências Farmacêuticas, Faculdade de Ciências Farmacêuticas de Ribeirão Preto, Universidade de São Paulo

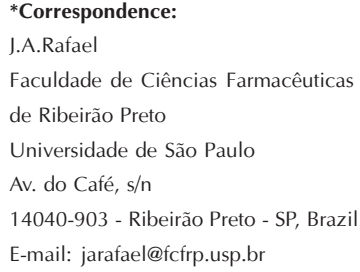

\begin{abstract}
Mesalamine (5-aminosalicylic acid, 5-ASA) is used because of its local effects in the treatment of inflammatory bowel disease. Therefore, the aims of this work were to compare and validate three analytical methods for the quality control of commercial coated tablets containing 5-ASA: high performance liquid chromatography (HPLC), 1,1diphenyl-2-picrylhydrazyl radicals (DPPH') and nitrosation. The parameters linearity, precision and accuracy were studied in this work. HPLC with ultraviolet detection at $254 \mathrm{~nm}$ was carried out with a C18 column and a mobile phase constituted of $30 \mathrm{mmol} / \mathrm{L}$ monobasic phosphate buffer ( $p H$ 7.0) and methanol (70:30; v/v), with 25\% tetrabutylammonium hydrogen sulphate. The DPPH method was performed at $517 \mathrm{~nm}$ and using $100 \mathrm{mmol} / \mathrm{L}$ acetate buffer, $\mathrm{pH} 5.5$, ethanol and $250 \mu \mathrm{mol} / \mathrm{L}$ ethanolic solution of DPPH. The nitrosation method was accomplished by using a platinum electrode and standard $0.1 \mathrm{~mol} / \mathrm{L}$ sodium nitrite as titrant solution. Repeatability (intra-day) and intermediate precision (inter-day), expressed as RSD, were lower than 3\%. The experimental recoveries were between 72.5 and $99.9 \%$. Statistical analysis by one-way ANOVA, followed by the multiple comparison test of Bonferroni showed no significant difference among the three methods. All proposed methods can be used for the reliable quantitation of 5-ASA in pharmaceutical dosage forms.
\end{abstract}

Uniterms

- Mesalamine

- High performance liquid chromatography

- 1,1-diphenyl-2-picrylhydrazyl radicals

- Nitrosation

- Validation

- Pharmaceutical dosage forms

\section{INTRODUCTION}

Mesalamine (5-aminosalicylic acid, 5-ASA) (Figure 1) is used for its local effects in the treatment of inflammatory bowel disease, including ulcerative colitis and Crohn's disease (Cai et al., 2003; Gotti et al., 2001). Despite the fact that it has been used for over 50 years, the mechanism of action of this drug remains uncertain. 5-ASA has been shown to be a potent scavenger of reactive oxygen species that play a significant role in the pathogenesis of inflammatory bowel disease, inhibition of natural killer cell activity, inhibition of antibody synthesis, inhibition of cyclo-oxygenase and lipoxygenase pathways and impairment of neutrophil function (Geier, Miner, 1992; Palumbo et al., 1995). 


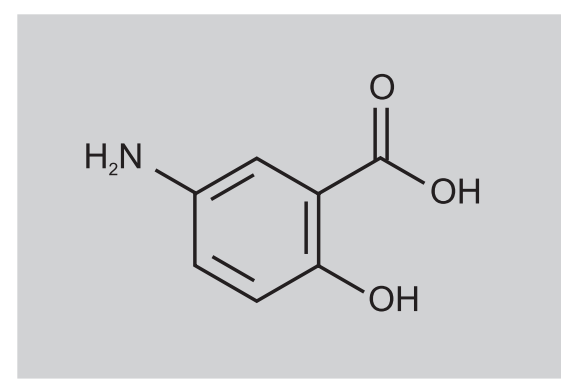

FIGURE 1 - Structure of 5-ASA.

This drug is unstable under gastric conditions and prone to be absorbed in the upper intestine, which causes low drug bioavailability and low efficiency against inflammatory colon disease. Therefore, colon-specific delivery of 5-ASA is an important issue (Cai et al., 2003).

Among 5-ASA colon-specific prodrugs, the earliest accepted drug is sulfasalazine, an azo-conjugate of 5-ASA with sulfapyridine, but this drug presents adverse effects due to sulfapyridine. Four novel delivery mechanisms have been developed to delay the release of 5-ASA until it reaches the colonic site of inflammation: (1) 5-ASA conjugated to an inert molecule; (2) 5-ASA conjugated to an other 5-ASA molecule; (3) 5-ASA enveloped in a delayed-release coating and (4) 5-ASA enveloped in a pHsensitive coating (Cai et al., 2003; Geier, Miner, 1992).

Polymeric prodrugs with 5-ASA can successfully deliver 5-ASA to the colon (Cai et al., 2003). Asacol ${ }^{\circledR}$, an oral commercial formulation containing $400 \mathrm{mg}$ of 5-ASA coated with acrylic resin (Eudragit S resin), delivers the drug at alkaline $\mathrm{pH}$ (Riley, Turnberg, 1990).

Since the drug is widely used in the treatment of inflammatory bowel disease, it is important to compare and validate analytical methods for its determination in pharmaceutical dosage forms.

Current literature reports few methods to quantify 5ASA in pharmaceutical dosage forms. A HPLC method adopted by the United States Pharmacopoeia 24 ed. is based on the mobile phase containing tetrabutylammonium hydrogen sulphate as an ion-pairing agent, which shortens column life. Moreover, mobile phase preparation requires tedious procedures.

On the other hand, the structural characteristic of 5ASA allows the use of other quantitative methods. Since antioxidant properties have been attributed to 5-ASA because it is a phenolic compound (Dinis, Madeira, Almeida, 1994), antioxidant activity can be used as an indirect method for 5-ASA quantitation. The DPPH' method is economic, simple, rapid and widely used to determine the antioxidant activity of phenolic compounds. A nitrosation method can be used to classify amines as primary (-NH2), secondary (-NHR), or tertiary (-NR2). The derivative products change according to whether the amine being tested is aliphatic or aromatic, and according to its substitutions. Primary aromatic amines react with nitrous acid to form diazonium salts, which are stable at $0{ }^{\circ} \mathrm{C}$ but decompose to nitrogen gas at room temperature. Due to the formation of a diazonium salt, the method can be used as a quantitative method, applying potenciometric titration. It is a simple procedure and a reproducible method.

The present work reports the comparison and validation of the HPLC, DPPH ${ }^{\circ}$ and nitrosation methods to quantify 5 -ASA in coated tablets (Asalit ${ }^{\circledR} 400 \mathrm{mg}$ ). The work describes analytical parameters that are very important for the validation of an analytical procedure, such as accuracy and specificity.

\section{MATERIAL AND METHODS}

\section{Chemical}

A 5-ASA reference standard was obtained from Acros Organics (New Jersey, USA). The pharmaceutical dosage form (Asalit ${ }^{\circledR} 400 \mathrm{mg}$ ) containing 5-ASA was kindly supplied by Galena (Campinas, SP, Brazil). All other reagents used were of pharmaceutical grade or HPLC grade. All solutions were prepared daily.

\section{Experimental apparatus and analytical condition}

The HPLC method was performed on a LC-10AT (Shimadzu Corporation, Tokyo, Japan) equipped with a $20 \mu \mathrm{L}$ loop and SPD-10A UV/VIS detector (Shimadzu). Integration of the chromatographic peaks was achieved with C-R6A Chromatopac integrator (Shimadzu). The analysis was performed by using a SuperPac Sephasil C18 column (particle size: $5 \mu \mathrm{m} ; 250$ x $4.0 \mathrm{~mm}$ i.d.; SuperPac Sephasil), and samples were isocratically eluted with a $30 \mathrm{mmol} / \mathrm{L}$ monobasic phosphate buffer (pH 7.0) and methanol (70:30; $\mathrm{v} / \mathrm{v})$, containing $25 \%$ tetrabutylammonium hydrogen sulphate, with the flow rate set at $1.0 \mathrm{~mL} / \mathrm{min}$. Each sample was filtered prior to injection using a Millex LCR filter (Millipore Corporation, São Paulo, SP, Brazil) and a $20 \mu \mathrm{L}$ aliquot was injected into the HPLC apparatus with UV detection at $254 \mathrm{~nm}$ (USP 24, 2000).

The DPPH' method was performed on a UV-VIS Spectrophotometer U2001 (Hitachi) at $517 \mathrm{~nm}$, using 1.0 $\mathrm{cm}$ quartz cells. The antioxidant activity was determined by the hydrogen-donating ability of 5-ASA. For radical scavenging activity measurements, $1 \mathrm{~mL}$ of $100 \mathrm{mmol} / \mathrm{L}$ 
acetate buffer, $\mathrm{pH} 5.5,1 \mathrm{~mL}$ of ethanol, $0.5 \mathrm{~mL}$ of $250 \mu \mathrm{mol} / \mathrm{L}$ ethanolic solution of $\mathrm{DPPH}^{*}$ was mixed, and $10 \mu \mathrm{L}$ of different concentrations of 5-ASA were added. The absorbance was measured after $10 \mathrm{~min}$ at $517 \mathrm{~nm}$, according to the method described by Dinis et al (1994). The blank was prepared from the reaction mixture without $\mathrm{DPPH}^{\circ}$ solution. All measurements were performed in triplicate.

The nitrosation method was conducted according to Korolkovas (1988). The potentiometric titration procedure was carried out using a platinum electrode as indicator electrode and a Micronal B374 pHmeter was used.

$0.1 \mathrm{~mol} / \mathrm{L}$ sodium nitrite solution was used as titrant. Mesalamine samples was dissolved in $0.005 \mathrm{~mol} / \mathrm{L} \mathrm{HCl}$ and cooled in an ice bath. The samples were titrated with $0.1 \mathrm{~mol} / \mathrm{L}$ sodium nitrite and the diazonium salts formed were determined potentiometrically.

\section{Preparation of the standard solutions and sample solutions}

\section{Preparation of tablet samples}

In order to acquire the sample solutions, 5 coated tablets were individually accurately weighted and their average weight was estimated. These 5 tablets were triturated one at a time to a powder. The remaining blended powder was used to prepare the sample solutions.

\section{HPLC method}

An amount of tablets powder corresponding to 25 $\mathrm{mg}$ of mesalamine was weighted and diluted to obtain a solution with $10 \mu \mathrm{g} / \mathrm{mL}$ final concentration in the mobile phase solution. The analytical curve was prepared with standard mesalamine in final concentrations of $0.25-100 \mu \mathrm{g} / \mathrm{mL}$, originally acquired from a $1000 \mu \mathrm{g} / \mathrm{mL}$ mesalamine stock solution. All samples were prepared in triplicate.

\section{1,1-diphenyl-2-picrylhydrazyl radical (DPPH') method}

Coated powdered samples were weighted to obtain the equivalent to $50 \mathrm{mg}$ of mesalamine, and this powder was diluted with a $30 \mathrm{mmol} / \mathrm{L}$ monobasic phosphate buffer (pH 7.0) and methanol (70:30; v/v), containing $25 \%$ tetrabutylammonium hydrogen sulphate in order to obtain a $500 \mu \mathrm{g} / \mathrm{mL} .10 \mu \mathrm{L}$ this solution was used for the reactions in order to obtain a $2 \mathrm{mg} / \mathrm{mL}$ mesalamine solution. The analytical curve was prepared with standard mesalamine in the concentration range of $0.4-4 \mu \mathrm{g} / \mathrm{mL}$ in the reaction medium. All samples were prepared in triplicate.

\section{Nitrosation method}

Accurately weighted amounts of tablets powder equivalent to $100 \mathrm{mg}$ of mesalamine were diluted with $0.005 \mathrm{~mol} / \mathrm{L} \mathrm{HCl}$ (and deionized water). The solution was cooled in an ice bath. A potentiometric titration procedure was performed by reaction of the aromatic amine (mesalamine) with the titrant solution $(0.1 \mathrm{~mol} / \mathrm{L}$ of sodium nitrite) in order to produce $N$-nitrosamines (diazonium salts). Low temperatures are required in the procedure to avoid diazonium salt decomposition. A platinum electrode was used as indicator electrode. A $100 \mathrm{mg}$ mesalamine reference standard underwent the same sample treatment as the analyzed sample. The analyses were conducted in triplicate.

\section{Method validation}

\section{Linearity}

The analytical curve was obtained with different concentrations ( 10 for HPLC and 6 for $\mathrm{DPPH}^{\circ}$ ) of the standard solution $(0.25-100 \mu \mathrm{g} / \mathrm{mL}$ for HPLC method and $0.4-3 \mu \mathrm{g} / \mathrm{mL}$ for the $\mathrm{DPPH}^{*}$ method). The solutions were prepared in triplicate. The linearity was evaluated by linear regression analysis (Raggi et al., 2000).

Since the titration methods do not need an analytical curve, linearity was not estimated for nitrosation method.

\section{Precision}

The precision of the assay was determined by repeatability (intra-day) and intermediate precision (interday). Repeatability was evaluated by assaying samples at same concentration during the same day. Intermediate precision was studied by comparing the assays on different days (3 days). Six sample solutions $(10 \mu \mathrm{g} / \mathrm{mL}$ for HPLC method, $2 \mu \mathrm{g} / \mathrm{mL}$ for DPPH' method and $100 \mathrm{mg}$ for nitrosation method) were prepared (Mendez, Steppe, Schapoval, 2003).

\section{Accuracy}

The accuracy was determined by recovery of known amounts of 5-ASA reference standard added to the samples at the beginning of the process. Established amounts of standard mesalamine were added to known amounts of triturated coated Asalit ${ }^{\mathbb{R}}$ tablets powder to obtain 3 different concentration of addition. Samples were assayed and recovery percentages for each standard concentration were estimated. The analyses were carried out in triplicate (Gotti et al., 2001).

The recovery percentage of the 5-ASA standard added was calculated using the equation proposed by AOAC (1990). 


\section{RESULTS AND DISCUSSION}

\section{HPLC method}

HPLC is method widely used in the quality control of drugs. Several HPLC methods have been used to measure the concentration of 5-ASA in biological fluids (Gotti et al., 2001).

The HPLC method adopted by the United States Pharmacopoeia uses a mobile phase containing tetrabutylammonium hydrogen sulphate as an ion-pairing agent (USP 24, 2000). Although the column life is decreased by that compound, the addition of tetrabutylamonium hydrogen sulphate is important in order to improve the separation due to the ion-par interactions of the ammonium salts with the anionic solutes (Cendrowska et al., 1990). Thus, 5-ASA present in coated tablet Asalit ${ }^{\circledR} 400 \mathrm{mg}$ was determined by the HPLC method proposed by the United States Pharmacopoeia.

Figure 2 shows standard solution (A) and sample solution (B) typical chromatograms obtained from the 5ASA analyses using the proposed method. As shown in the results, the standard and sample solutions were eluted at the same retention time $(2.89 \mathrm{~min})$ allowing a rapid determination of the drug, which is important for routine analysis. The chromatograms present symmetrical peaks and the base line was free of interference for both standard and sample solutions. Cendrowska et al. (1990) examined two HPLC methods to separate 5-ASA from other drugs, and the retention time obtained was higher than $7 \mathrm{~min}$. Thus, the proposed methodology is faster than that described by Cendrowska et al. (1990).

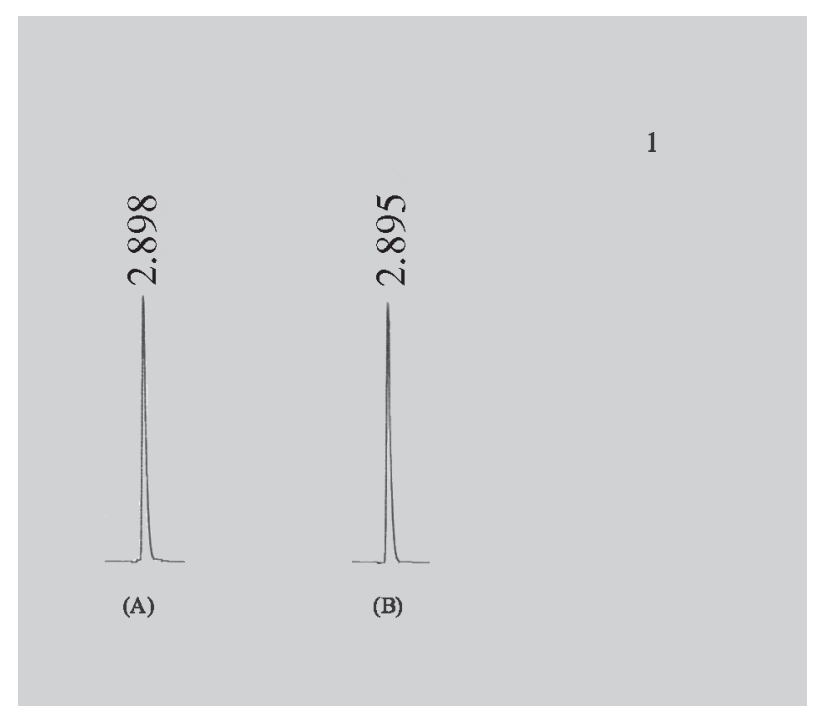

FIGURE 2 - HPLC chromatograms of 5-ASA reference standard (A) and 5-ASA present in coated tablet Asalit ${ }^{\mathbb{B}}$ $40 \mu \mathrm{g} / \mathrm{mL}$ (B).
The analytical curve for 5-ASA was constructed by plotting drug concentration versus peak height and showed good linearity in the $0.25-100 \mu \mathrm{g} / \mathrm{mL}$ range. The representative linear equation was $\mathrm{y}=437.41 \mathrm{x}+60.915$, with a correlation coefficient $(r=0.999)$ highly significant for the method (Table I).

Method precision was determined by repeatability (intra-day) and inter-day intermediate precision (inter-day) tests and was expressed as RSD (relative standard deviation) $(\%)$ of a measurement series. The analytical parameters obtained for the determination of 5-ASA by the HPLC method are presented in Table II. The experimental values obtained over 3 days for a measurement series of a $10 \mu \mathrm{g} / \mathrm{mL}$ solution showed $1.75 \%$ RSD, indicating good inter-day precision. Intra-day variability showed a mean RSD of $2.51 \%$. Haney and Dash (1997) validated the HPLC method for 5-ASA assay and the intra and inter-day precisions obtained were $1.2-4.6 \%$ and $1.1-3.5 \%$, respectively.

The USP and AOAC indicate, in general, RSD values lower 2\% (AOAC, 1975; Parejo et al., 2000). According to Raggi et al (2000) the RSD value should be lower than 3\%. Therefore, the precision of this method is within the expected range.

The accuracy of the method was determined by addition of three different concentrations of standard in the samples, in triplicate, and the mean recovery percentage was found to be $88.2 \%$ (Table III). In general, the recovery percentage as a measure of the accuracy should be close to 100\% (AOAC, 1975; Parejo et al., 2000).

\section{1,1-diphenyl-2-picrylhydrazyl radicals (DPPH') method}

$\mathrm{DPPH}^{*}$ is a stable free radical potentially reactive with substances able to donate a hydrogen atom and, thus, useful to assess antioxidant activity of specific compounds of extracts (Dinis, Madeira, Almeida, 1994). Because of its odd electron, $\mathrm{DPPH}^{\circ}$ has a strong absorption band at $517 \mathrm{~nm}$. Since this electron becomes paired in the presence of a free radical scavenger, the absorption decreases stoichiometrically with respect to the number of electrons taken up. This change in absorbance produced by this reaction has been widely used to test the ability of several molecules to act as free radical scavengers (Dinis, Madeira, Almeida, 1994).

Various investigations have shown that 5-ASA presents antioxidant activity (Dinis, Madeira, Almeida, 1994) demonstrated the antioxidant activity of 5-ASA compared to other antipyretic and anti-inflammatory drugs, and indicated that 5-ASA acts as a potent free radical scavenger, in a way similar to ascorbate, in contrast with salicylate which does not react with DPPH'. Among the compounds tested, 5-ASA presented the highest antioxidant activity (Dinis, Madeira, Almeida, 1994). 
TABLE I - Regression analysis of the quantitation data of 5-ASA by two of the proposed methods

\begin{tabular}{lll}
\hline Statistical parameters & HPLC Method & DPPH Method $^{-}$ \\
\hline Regression equation $^{\mathrm{a}}$ & $\mathrm{y}=437.41 \mathrm{x}+60.915$ & $\mathrm{y}=10.707 \mathrm{x}-0.6435$ \\
Standard error of slope & 102.78 & 1.01 \\
Standard error of intercept & 1.88 & 0.00218 \\
Correlation coefficient $(\mathrm{r})$ & 0.999 & 0.999 \\
Concentration range $(\mu \mathrm{g} / \mathrm{mL})$ & $0.25-100$ & $0.4-3$ \\
\hline
\end{tabular}

$\mathrm{y}=\mathrm{ax}+\mathrm{b}, \mathrm{x}$ is the concentration of the drug in $\mu \mathrm{g} / \mathrm{mL}$ (HPLC method and DPPH' method) and $\mathrm{y}$ is peak high (HPLC method) or antioxidant activity (DPPH ${ }^{\cdot}$ method); ${ }^{\text {a }}$ Based on three calibration curves.

TABLE II - Analytical parameters obtained in validation of the proposed methods

\begin{tabular}{llll}
\hline & HPLC $(10 \mu \mathrm{g} / \mathrm{mL})$ & $\mathrm{DPPH}^{*}(2 \mu \mathrm{g} / \mathrm{mL})$ & Nitrosation $(100 \mathrm{mg})$ \\
\hline mean & $9.55 \mu \mathrm{g} / \mathrm{mL}$ & $2.31 \mu \mathrm{g} / \mathrm{mL}$ & $97.64 \mathrm{mg}$ \\
SD & 1.68 & 3.02 & 1.07 \\
RSD (\%) Intra-day & 2.51 & 1.50 & 1.93 \\
RSD $(\%)$ Inter-day & 1.75 & 2.60 & 1.09 \\
\hline
\end{tabular}

$\mathrm{SD}=$ standard derivation, $\mathrm{RSD}=$ relative standard deviation in percentage; ${ }^{3} 3$ days

TABLE III - Experimental values obtained in the recovery test for 5-ASA in commercially coated tablet

\begin{tabular}{llll}
\hline Method & Sample concentration & $\begin{array}{l}\text { Concentration of } \\
\text { added standard }\end{array}$ & $\begin{array}{l}\text { \% Recovery }{ }^{\mathrm{a}} \pm \\
\text { RSD }(\%)\end{array}$ \\
\hline${ }^{*} \mathrm{HPLC}$ & $30 \mu \mathrm{g} / \mathrm{mL}$ & $10 \mu \mathrm{g} / \mathrm{mL}$ & $98.0 \pm 4.63$ \\
& $30 \mu \mathrm{g} / \mathrm{mL}$ & $20 \mu \mathrm{g} / \mathrm{mL}$ & $75.5 \pm 1.80$ \\
& $30 \mu \mathrm{g} / \mathrm{mL}$ & $30 \mu \mathrm{g} / \mathrm{mL}$ & $91.0 \pm 2.00$ \\
${ }^{*} \mathrm{DPPH}$ & $200 \mu \mathrm{g} / \mathrm{mL}$ & $200 \mu \mathrm{g} / \mathrm{mL}$ & $72.5 \pm 2.00$ \\
& $200 \mu \mathrm{g} / \mathrm{mL}$ & $300 \mu \mathrm{g} / \mathrm{mL}$ & $82.5 \pm 2.30$ \\
& $200 \mu \mathrm{g} / \mathrm{mL}$ & $400 \mu \mathrm{g} / \mathrm{mL}$ & $81.4 \pm 1.38$ \\
Nitrosation & $50 \mathrm{mg}$ & $30 \mathrm{mg}$ & $99.9 \pm 1.60$ \\
& $50 \mathrm{mg}$ & $40 \mathrm{mg}$ & $97.9 \pm 1.28$ \\
& $50 \mathrm{mg}$ & $50 \mathrm{mg}$ & $95.9 \pm 1.80$ \\
\hline
\end{tabular}

${ }^{\mathrm{a}}$ Mean of three determination; * Aliquot of $20 \mathrm{~mL}$ and $10 \mathrm{~mL}$ of the solutions were used for the HPLC and DPPH methods, respectively.

In the present study, the antioxidant activity was determined by the ability of 5-ASA to donate hydrogen atoms to DPPH'. It was utilized in order to quantify 5-ASA in Asacol ${ }^{\circledR} 400 \mathrm{mg}$ coated tablets, using spectrophotometric methods, and this was compared to other methodologies proposed to quantify 5-ASA.

5-ASA caused an instantaneous decrease in DPPH ${ }^{\circ}$ absorbance, when compared to the control absorbance, suggesting that the commercial coated tablets present high antioxidant activity.
A concentration-response curve was constructed by plotting 5-ASA concentration versus free radical scavenger activity and linearity was obeyed for the range of $0.4-3 \mu \mathrm{g} / \mathrm{mL}$ in the reaction medium. The representative linear equation was $\mathrm{y}=10.707 \mathrm{x}-0.6435$, with a correlation coefficient of 0.999 (Table I).

Table II shows the analytical parameters obtained for the determination of 5-ASA by the DPPH' method, using a $2 \mu \mathrm{g} / \mathrm{mL}$ solution in order to acquire the measurement series. The results indicate satisfactory intra-day variability 
$(1.50 \% \mathrm{RSD})$ and inter-day variability $(2.60 \% \mathrm{RSD})$. The accuracy of the method was determined. However, the mean recovery percentage was $78.8 \%$ (Table III), which is under the recommended recovery percentage value of $100 \%$

\section{Nitrosation method}

Amine nitrosation is a quantitative analytical method that uses a standard sodium nitrite solution as titrant. The titration is carried out an acidic environment. Nitrous acid reacts quantitatively with aromatic amines producing diazonium salts. Since it is a simple and reproducible method, it can be used to quantify 5-ASA, which is an aromatic amine, present in commercial coated tablets.

Experimental data obtained when 5-ASA was quantified through the nitrosation method were used to set the analytical parameters show in Table II. The results show a $1.11 \%$ RSD, pointing to a satisfactory intra-day variability, and a $1.09 \%$ RSD inter-day variability. The accuracy of the method was estimated and the mean recovery percentage was found to be $97.2 \%$.

Comparison between proposed methods

The proposed analytical methods were compared using statistical analysis. Data were statistically analyzed by one-way ANOVA, followed by the Bonferroni multiple comparison test and do not show significant differences among the methods, considering $P>0.05$.

HPLC and DPPH ${ }^{*}$ methods had very similar precisions, both inside the acceptable limit. HPLC had a better recovery percentage than $\mathrm{DPPH}^{\circ}$, which showed recoveries under the limit suggested by AOAC (1975).

\section{CONCLUSIONS}

HPLC, DPPH ${ }^{\circ}$ and nitrosation are all suitable methods for a reliable quantitation of 5-ASA in commercial coated tablets in terms of analytical parameters. There were no significant statistical differences among the proposed methods. It should be noted that all methods showed similar and favorable results with respect to precision and accuracy. The RSD values are all lower than 3\%. However, the nitrosation method showed the best recovery percentage and it was the most precise method, as well as being the simplest and most inexpensive methodology. The proposed methods have the advantage of using feasible analytical procedures and need only a simple preparation of the samples. Therefore, they can be used for the drug analysis in routine quality control.

\section{RESUMO}

\section{Validação dos métodos de CLAE, DPPH`e nitrosação para determinação de mesalazina em formas farmacêuticas}

Mesalazina (ácido 5-aminosalicílico, 5-ASA) é utilizado devido seu efeito local no tratamento de doença inflamatória intestinal. Assim, o objetivo deste trabalho foi comparar e validar três métodos analíticos para o controle de qualidade de comprimidos comerciais revestidos contendo 5-ASA: cromatografia líquida de alta eficiência (CLAE), radical 1,1-difenil-2-picril-hidrazil (DPPH') e nitrosação. Os parâmetros linearidade, precisão e exatidão foram estudados neste trabalho. CLAE com detecção ultravioleta em $254 \mathrm{~nm}$ foi realizada utilizando coluna C18 e a eluição em fase móvel constituída de tampão fosfato monobásico $30 \mathrm{mmol} / \mathrm{L}(\mathrm{pH} 7,0)$ e metanol $(70: 30 ; \mathrm{v} / \mathrm{v})$, com $25 \%$ de sulfato hidrogênio de tetrabutilamônio. Para o método de $D P P H \cdot$ utilizou-se tampão acetato $100 \mathrm{mmol} / \mathrm{L}, \mathrm{pH} \mathrm{5,5}$, álcool etílico e $250 \mu \mathrm{mol} / \mathrm{L}$ solução etanólica de DPPH' a $517 \mathrm{~nm}$. Para o método de nitrosação utilizou-se um eletrodo de platina e um padrão de nitrito de sódio $0.1 \mathrm{~mol} / \mathrm{L}$ como solução titulante. Repetibilidade (intra-dia) e precisão intermediária (inter-dia), expressado como DPR, foi menor que 3\%. A recuperação experimental foi entre 72,5 e 99,9\%. Análise estatística por "one-way" ANOVA, seguida de comparação múltipla do teste de Bonferroni, não mostrou significância entre os três métodos. Os métodos propostos podem ser usados para análise quantitativa do5ASA em formas farmacêuticas.

UNITERMOS: Mesalazina. Cromatografia líquida de alta eficiência. 1,1-difenil-2-picril-hidrazil. Nitrosação. Validação. Forma farmacêutica.

\section{ACKNOWLEDGMENTS}

This work was supported by Conselho Nacional de Desenvolvimento Científico e Tecnológico (CNPq), Fundação de Amparo à Pesquisa do Estado de São Paulo (FAPESP) and Coordenação de Aperfeiçoamento de Pessoal de Nível Superior (CAPES). Janice A. Rafael received a fellowship from CNPq. The authors would like to thank Galena (Campinas, SP, Brazil) for supplying 5-ASA.

\section{REFERENCES}

ASSOCIATION OF OFFICIALANALYTICALCHEMISTS. Official Methods of Analysis. 15. ed. Arlington: Association of Official Analytical Chemists, 1990. v.1,p. 17. 
ASSOCIATION OF OFFICIAL ANALYTICAL CHEMISTS. Statistical Manual of the AOAC. 12 ed.Washington: AOAC, 1975. p. 1094.

CAI, Q. X.; ZHU, K. J.; CHEN, D.; GAO, L. P. Synthesis, characterization and in vitro release of aminosalicylic acid and 5-acetyl aminosalicylic acid of polyanhydrine $-\mathrm{P}$ (CBFAS). Eur. J. Pharm. Biopharm., Amsterdam, v. 55, p. 203-208, 2003.

CENDROWSKA, I.; DREWNOSKA, A.; GRZESZKIEWICZ, A.; BUTKIEWICZ, K. Investigation of the stability of 5-aminosalicylic acid in tablets and suppositories by high-performance liquid chromatography. J. Chromatogr., Amsterdam, v. 509, p. 195-199, 1990.

DINIS, T.C.P.; MADEIRA, V.M.C.; ALMEIDA, L.M. Action of phenolic derivatives (acetaminophen, salicylate and 5-aminosalicylate) as inhibitors membrane lipid peroxidation and peroxyl radical scavengers. Arch. Biochem. Biophys., New York, v. 315, n.1, p. 161-169, 1994.

GEIER, D.L.; MINER, P.B. New therapeutic agents in the treatment of inflammatory bowel disease. Am. J. Med., New York, v.93, n.2, p.208-298, 1992.

GOTTI, R.; POMPONIO R.; BERTUCCI, C.; CAVRINI, V. Determination of 5-aminosalicylic acid related impurities by micellar electrokinetic chromatography with an ionpair reagent. J. Cromatogr. A, Amsterdam, v. 916, p. 175$183,2001$.

HANAUER, S.B. Inflammatory bowel disease revisited: Newer drugs. Scand. J. Gastroenterol., Oslo, v. 25, n. 175, p. $97-106,1990$.

HANEY, P.W.; DASH, A.K. Simple liquid chromatographic method for the analysis of 5-aminosalicylic acid and its degradation product. J. Chromatogr. A, Amsterdam, v.765, p. 233-238, 1997.
KOROLKOVAS, A. Análise farmacêutica. Rio de Janeiro: Guanabara Koogan, 1988. p.159.

MENDEZ, A.S.L.; STEPPE, M.; SCHAPOVAL, E.E.S., Validation of HPLC and UV spectrophotometric methods for the determination of meropenem in pharmaceuticcal dosage form. J. Pharm. Biomed. Anal., Oxford, v.33, p.947-954, 2003.

PALUMBO, G.; CARLUCCI, G.; MAZZEO, P. et al., Simultaneous determination of 5-aminosalicylic acid, acetyl-5-aminosalicylic acid and 2, 5-dihydroxybenzoic acid in endoscopic intestinal biopsy samples in humans by high-performance liquid chromatography with electrochemical detection. J. Pharm. Biomed. Anal., Oxford, v.14, p.175-180, 1995.

PAREJO, I.; CODINA, C.; PETRAKIS, C.; KEFALAS, P. Evaluation of scavenging activity assessed by Co (II)/ EDTA-induced luminol chemiluminescence and DPPH (2,2-diphenyl-1-picrylhydrazyl) free radical assay. $J$. Pharmacol. Toxicol. Methods, New York, v.44, p.507512, 2000.

RAGGI, M.A.; CASAMENTI, G.; MANDRIOLI, R.; IZZO, G.; KENNDLER, E. Quantitation of olanzapine in tablets by HPLC, CZE, derivative spectrometry and linear voltammetry. J. Pharm. Biomed. Anal., Oxford, v.23, p. $973-981,2000$.

RILEY, S.A.; TURNBERG, L.A. Sulphasalazine and the aminosalicylates in the treatment of inflammatory bowel disease. Q. J. Med., Oxford, v.75, n.278, p. 551-562, 1990.

UNITED States Pharmacopeia 24. ed. Rockville, United States Pharmacopeial Convention, 2000. [CD-ROOM].

Recebido para publicação em 17 de agosto de 2005. Aceito para publicação em 01 de dezembro de 2006. 